\title{
WILLARD LEAROYD SPERRY
}

Born, at Peabody, Massachusetts, April 5, 1882

Died, at Boston, Massachusetts, May 15, 1954

Forty-two years ago Dean Sperry contributed to the Harvard Theological Review 'The Eschatology of the Synoptic Gospels: Its Fidelity to Religious Experience ( V, 1912, $385 \mathrm{ff}$.), his first theological paper. This was followed by his beautiful study of Mark Rutherford (VII, 1914, 166 ff.) and by other articles; among these 'The Call to the Ministry' (XV, 1922, 217 ff.) made a particular impress. The Harvard Theological Review is deeply in his debt for these things, even as it is for his twenty years of service on the Editorial Board and for his unfailing helpfulness in all its problems. The Divinity School, the University, and the far wider community that has gained so much from his personality and his spoken and written word have cause for unbounded gratitude. 